\title{
The motivation to use oral language in the EFL classroom in ESO and Bachillerato
}

\author{
Rosario Padial Campón \\ Elena TAPia Carrillo \\ Faculty of Education, University of Granada
}

Received: 12 February 2006 / Accepted: 4 May 2006

ISSN: $1697-7467$

\begin{abstract}
The students' general inhibition to use L2 in the classroom is a reality which every teacher has experienced. The purpose of this research is to observe and describe the reasons for this reality from the students' perspective and obtain some conclusions which can help teachers to improve the situation. A survey was passed among students of ESO and Bachillerato as well as among their teachers. This showed that students must be intrinsically motivated and the teacher must help them to raise their self- worth and reach autonomy. This seems to be the most important factor although there are some others such as interactive pattern, feedback and the role of the teacher itself. The reality reflected by the surveys is totally opposed to the most current methodological tendencies. Key words: motivation, inhibition, oral use of the target language, learning autonomy, secondary school
\end{abstract}

Resumen: La tendencia general del alumno a inhibirse en el uso oral de la lengua meta en el aula es una realidad que todo profesor ha podido experimentar. Nuestra finalidad es observar y describir las razones que explican esta situación desde la perspectiva del alumno y obtener algunas conclusiones que puedan ayudar al profesor a solucionar dicha situación. Alumnos de ESO y Bachillerato fueron encuestados, así como sus profesores. La información recavada muestra que los alumnos deben estar intrínsicamente motivados y los profesores deben ayudarles a incrementar su autoestima y alcanzar autonomía de aprendizaje. No podemos dejar a un lado la importancia de los esquemas de interacción, la corrección y del papel del profesor. Sin embargo, la realidad reflejada por los resultados de las encuestas es bastante opuesta a las corrientes metodológicas actuales.

Palabras clave: motivación, inhibición, uso oral de la lengua meta, autonomía en el aprendizaje, enseñanza secundaria

\section{INTRODUCTION}

There are a certain number of factors that prevent students from using orally the English language in the classroom. There are some conditions that may cause or hinder such use of the language.

Motivation has always been regarded as one of the main factors which influence the students' behaviour in the classroom and therefore the frequency of occurrence of their oral production. 
McLaren and Madrid (1996: 144-145) pointed out four main factors which influence the students' motivation in the classroom:

1) Value that the students give to the subject regarding its use in their future career.

2) The extent to which they like the subject as compared to others which do not include any communicative activity, songs, or games.

3) Wish to live immersed in the Anglo-Saxon culture.

4) Influence of the teacher

Regarding motivation, these will be the basic factors that we will try to analyse together with other different aspects.

Spratt, Humphreys and Chan, (2002) tried to analyse whether learning autonomy preceded motivation or it was the reverse. From their conclusions, it is easy to draw that if a student is motivated he/she will develop learning autonomy. This autonomy will certainly have positive effects on their learning process, but what is relevant now is that it will allow them to use the oral language in an uninhibited way. Thus, our first premise in this paper is that if a student is motivated, he/she will use the language autonomously without restrictions. This is also supported by Littlewood (1992), who thinks that motivation must necessarily exist before achieving learning autonomy.

Now the question was how to raise that level of motivation in the classroom so that it allows students to achieve their goals inside and outside the classroom. Spratt et al. (2002) propose some ways to do so such as helping students believe in the effectiveness of their own efforts, engaging in activities and working with materials and syllabuses which learners wish to engage in, adopting a learner-centred approach to teaching, recognising the diversity of learning styles, and of course, being a model of motivation.

Nikolov (1999) analyses the students' motives to study English. These reasons could be classified into four main types: classroom-related reasons, teacher-related reasons, external reasons and utilitarian reasons. Those four items have also been taken into account in our research in order to provide more data regarding this issue. She also identified some factors which enhance motivation to learn a foreign language: the possibility to negotiate learning, student's self-steem and trust of their own ability, the need for success, and the value they give to a second language.

As Madrid (2004: 86) points out, students from Secundaria and Bachillerato agree that the didactic abilities of the teacher are far more important than his/her knowledge of the discipline. "Si el profesor sabe mucho inglés pero no sabe enseñarlo no aprendemos nada" (ibid. 114). They also agree that the teacher's motivation is the basis for their own motivation and behaviour in the classroom. The teacher's enthusiasm and interest will be more influential than his/her knowledge of the subject (ibid. 116).

Up to this point, the assumption is that students' oral participation in L2 is partly determined by some non-linguistic and non-cognitive factors. It could include, as commented above, the motivation, but there are other variables such as the influence of their partners. The interpersonal relationship between the two participants, at least, is a relevant determinant to obtain the best result. If there is not a good relationship, students don't participate, so the activities are unlikely to be effective in those communicative contexts. 
There are others factors such as the linguistic self-confidence or the language ego (Hernández, Hornillo, y Picó (1991) that may influence the improvement or participation of a learner in L2 or the learner's opinion about the importance of English in their future. In addition, the personal characteristics as shyness or anxiety could be the reason why some students prefer not to participate orally. In all these situations, it is necessary that the filter is "down" because in oral communication, if participation is avoided, the exercise is a disaster. (Krashen, Dulay, Burt, 1982)

The student's trust on their own ability has been analysed by Covington (1985). He calls it the "motive of self-worth", which also has to do with an unconscious tendency towards the protection of the self. He claims that a combination of little rewards and a non-justified emphasis on ability forces many students to struggle simply to avoid failure rather than to strive for success. And the most direct way to avoid school failure is simply not to participate. According to Covington, unwillingness to do work that is not absolutely required or doing as little as possible on required assignments, absenteeism and chronic inattention are other ways of avoiding failure and participation. If students participate and fail, they shift the personal causes of failure away from the internal attribution of ability towards external factors beyond the individual's control of responsibility.

Another important factor is the role that the teacher takes. (Zang and Aiex, 1995). Teacher-dominated classrooms will provide the main reason for the students' lack of use of the target language. Zang and Aiex et al. (1995) present the oral use of the language as the basis for the development of every other skill and/or cognitive process. These authors conclude that the teacher must take the role of friend and facilitator of the students' learning. They must give students the chance to speak and explore their own thinking. This usually leads to the criticism of excessive TTT (teacher talking time), being the general advice to reduce it as much as possible.

Other analyses of TTT, such as the one carried out by Steve Walsh (2002), show that TTT cannot be analysed in terms of quantity but of quality. As long as it fits the pedagogic purpose, teacher's talk is justified. One of the main evidences for this is the one pointed out by Foster (1998). He explains that negotiation of meaning is one of the key elements for the development of the oral skills. Teachers create opportunities for learning in their choice of language and they also involve the students in the tasks. On the other hand, there are also some features of this teacher's language use which hinder learner involvement: turn completion, teacher echo for the rest of the students to listen, and teacher interruptions.

Teachers' error correction occurs frequently, irrespective of pedagogical focus and classroom setting and learners at L2 don't consider it frustrating. Researchers have used four mayor direct or indirect measures of the effectiveness of corrective feedback in language acquisition (YoungHee Sheen, 2004): up-take, immediate, post-test, learner perception. Walsh (2002) thinks that error correction should be reduced to the minimum in oral fluency practice activities in order to reduce interruption and "maintain the flow".

Halliday (1989: 25) explains that "spoken language represents phenomena as processes. Written language represents phenomena as products and this corresponds to the difference between written and spoken discourse." Students may be afraid of showing that process. They cannot prepare their production previously due to the fact that speaking occurs in real time so they have to assume the risk of making mistakes. They want to present their discourse like a product, however it is not possible. It is the task of the teacher to encourage them to show 
such product even though it includes mistakes. This means a change of perspective in the teacher's way to provide feedback. However, there is not much literature about the learners' opinion about these methods. This is another aspect our research will focus on.

It is also important to consider speaking as related to the other skills as it is rarely learnt in isolation. The teacher can present the skills integrated, which may motivate the students. As we find in Oxford (2001), there are two types of integrated skill instruction: in the content-based language instruction, students practise all the language skills integrated in the content; in the task-based instruction, students participate in communicative tasks in English. The interaction is normally in pair-work, group-work, or other cooperative-learning format.

The purpose of this paper is to report observations and analysis of data directly obtained in some Spanish high schools so that the achieved conclusions can help us to provide some proposals to ameliorate the lack of use of L2 in the classroom by the students. Firstly, our purpose is to identify the possible factors which influence the students' rejection to use the FL in the oral mode. Then, it will follow an analysis of the essence of such factors to obtain conclusions about their origin, the extent of their influence, and how to prevent them. Finally, our discussion will provide some proposals which could prevent that influence on the students and allow them to develop communicative competence without any kind of restriction.

In order to achieve these objectives, the present research will offer an analysis of the following items: motivation to study L2; classroom management (organization and its relationship with students' feelings about it); preferred moment of using L2; motivation and lack of it to use L2 in the classroom; error correction and teacher's roles according to the students' views.

\section{MethoD}

\subsection{Participants}

The participants of the analysis discussed in this paper were 170 students aged from 14 to 18 both girls and boys studying English as a foreign language in three Spanish secondary schools. They were studying the $4^{\text {th }}$ level of ESO and the $2^{\text {nd }}$ level of Bachillerato. The reasons to select these levels were to observe the differences between a group highly conditioned by the University entrance exam and another one in which these conditions are not so relevant.

The teachers responsible for the instruction are also participants in this analysis, though our priority will be the students because they are the core of our research.

There was one public school and two other high schools which are not private but the parents have to pay a few amount of money. They were all well-regarded, but not particularly famous or elite schools. The socio-cultural level was medium-high. Two of them were sited in Granada city centre and the other one in a village. They provided general instruction and prepared students for further studies in higher education.

In all these schools they used course books published in Spain. The group sizes ranged from 15 to 32 (but not every student was present when the data reported here were gathered.)

Classes included mixed-ability students. Not all of them were good students and they presented many different attitudes towards English. 


\subsection{Instruments}

The instruments used for this research were the teacher's survey and the learner's survey. Both of them had the same objectives so their design followed a parallel structure and was based on the same items. There were, of course, some differences in terminology and in the perspective of each question. The features that the surveys shared are the following:

They should value each item according to a five-point scale, meaning each point as follows:

- 1: no, nothing, never

- 2: a few, something, sometimes, not so good, hardly ever

- 3: normal, average, acceptable

- 4: enough, almost always, good, important, satisfactory

- 5: always, a lot, very good, very important, excellent

Apart from that, each question included the possibility of adding comments about it, which provided us with qualitative data, not only the quantitative one.

The learner's survey consists of 18 questions. There is an introduction where the students fill-in some information their age, sex and level. From the first to the sixth question they give information about their experience with L2. In questions 7 and 8 the subjects are organized according to their preferences and the value they give them in relation to their professional future.

Questions 9 and 10 ask the same as questions 7 and 8 in a quantitative way.

In question 11 they should value if they talk in class in English as much as they would like. The following question is about the organization of the class as they are experiencing it. Then, questions $13,14,15$, and 16 are about the learners' preferences to talk in class according to their level of anxiety, shyness, interest in the content of the class, presence or absence of class mates and teacher, as well as some self-perceptions about pronunciation, knowledge and self-confidence. In question 17 they reflect on the way in which their teacher usually corrects their mistakes and how they would like it to be. Finally, in the last question they give their perception about the role of the teacher in the classroom.

The teacher's survey consists of ten questions. They will be evaluated according to the scale above.

The first part provided us with professional information about the teacher such as the teaching level and how many years they have been working. The first and fifth questions are oriented to gather information about their opinion on the time devoted to the different skills. Question 2 reflects the special requirements that the University entrance exam imposes. Questions 3 and 4 about the possible reasons why a teacher adopts a type of methodology and rejects others: grammatical knowledge, motivation and interest in L2. Question 6 is about the teacher's perception about the reasons why learners may not use L2 in the classroom: his urgency to cover curriculum requirements, lack of motivation towards specific topics or towards the subject as a whole, social and cultural factors, error correction reticence, risktaking avoidance. The next two questions focus on the way the teacher corrects students' mistakes and the moment to do so. Question 9 consists of a group of proposals to improve the possible lack of oral use of L2 in the classroom which the teacher will have to evaluate. Finally, the teacher gave his point of view about the different roles the teacher can play in the L2 classroom as far as they boost the oral use of the English language. 
The collected data were analysed by means of SPSS (Statistical Package for Social Sciences). It allowed the achievement of the conclusions explained below.

A filing card was also useful in order to analyse some classes as they proceeded every two minutes. It was possible to observe the quantity of TTT and STT as well as what they used the language for. Therefore, the main focus was on the four skills as well as on grammar explanation, checking homework, on the occurrence silences, and switches to the mother tongue.

\subsection{Procedure}

All the data collection of the study was carried out within the framework of the students' regular English classes. We administered the questionnaire and explained how to evaluate each item. They had 10 or 15 minutes to complete all questions. Throughout these minutes we answered specific questions raised by particular students.

The next step was to introduce the data in SPSS and to analyse the different items we were interested in. There were 41 items that we have classified under the following headings in order to facilitate our analysis:

- Personal data

- Students' extrinsic motivation

- Students' intrinsic motivation

- Value that the students assign to the use of L2 in general

- Classroom management

- Extent to which the students feel relaxed to use L2 according to:

a) partners' presence

b) teacher's presence

- Personal constraints to use L2

- Types of feedback as they prefer it

- Teacher's role

After introducing the items and data from the 170 surveys in SPSS, we focused on those aspects which were more relevant for our purpose, that is, analysing whether the students are motivated to learn a second language and hence to use it in the classroom as well as identifying what motivates and hinder them in order to use or stop using L2 in the classroom.

Thus, the first items of our questionnaire helped us to evaluate whether the students were motivated in general, not only intrinsically but also extrinsically. It was the reason to include items from 4 to 11 .

The next stage was to relate the students' success on passing the subject to classroom management, the role of the teacher, the type of feedback they prefer, and the value they give to English for their future career. This would allow us to draw some conclusions regarding the extent to which the students' success at English is affected by external factors like the teacher, the type of feedback they get, and classroom management, as well as by internal factors such as their own perception of the value of the subject. However, the most important fact for us when analysing this is that the given data do not correspond exactly to reality, but to the students' perception of it. 
Students' success is quite relevant for our research, but the central objective of it is the use of L2 in the classroom. Therefore the core of our analysis has to be the relationship between the extent to which the students use the language as much as they would like to and again the role of the teacher, classroom management, type of feedback and their perception of the use of the L2 in the classroom. The results from this combination of items will provide significant data since they reflect their own real perception of the circumstances that influence their motivation to use L2 in the classroom without any theoretical influence from us or the teacher.

There are two more aspects from which to draw important conclusions: the circumstances under which students feel more at ease in order to use L2 in the classroom and their own personal constraints as they perceive them, which determine the fact that they use or do not use L2. Seventeen items in our questionnaire served this purpose so that we could get a very specific picture of the circumstances under which the students preferred to speak in English and the reasons which might stop them from taking the risk.

According to all these criteria, we determined to comment only those factors that are unexpected for us when analysing the figures. Thus, it was possible to get the conclusions that confirmed or refuted our initial hypothesis with the results that follow.

\section{RESUlts}

The results obtained in our research are shown in the following figures and tables. Figure 1 shows students' extrinsic motivation as those students who are extrinsically motivated usually answered positively to these items. It is relevant to distinguish between the two levels studied: ESO and Bachillerato, as they show significant differences which raised some questions to discuss in our conclusions.

Figure 1. Students' extrinsic motivation

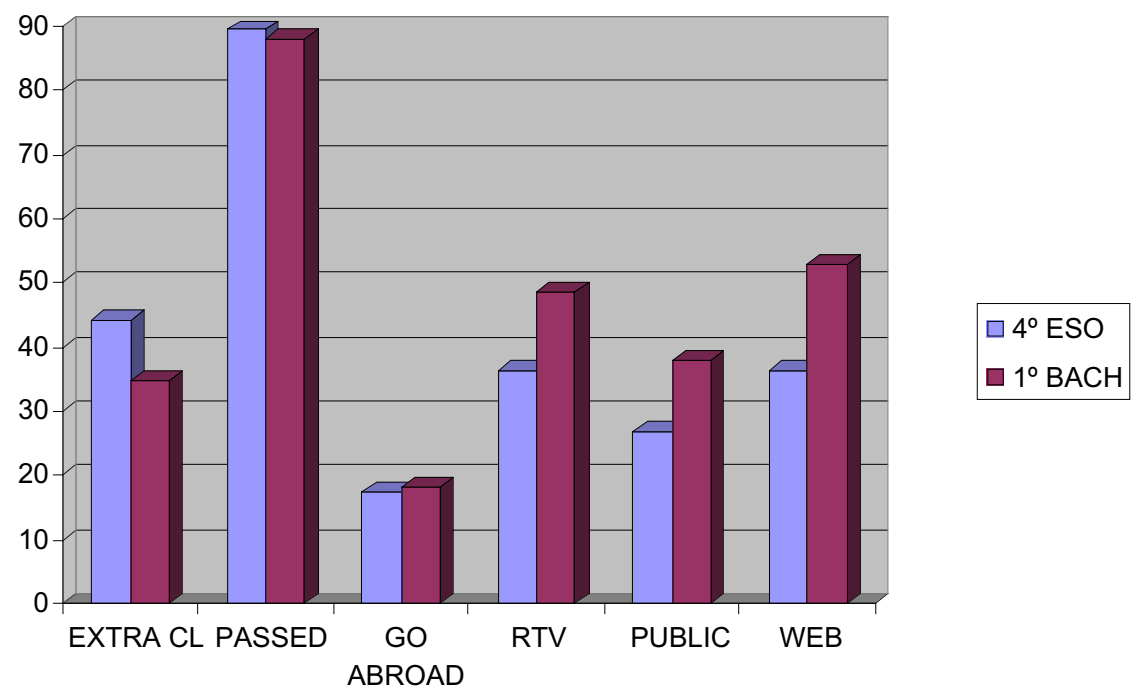


Table 1 presents a summary of the main part of the survey. The students had to evaluate them in a scale from 1 to 5, 1 meaning never, 2 sometimes, 3 normal, 4 almost always, and 5 always. The given results correspond to the mean of the values assigned to each item. They are also presented according to the level they refer to. They evaluate the students' motivation, their perception of the organization of the class, the circumstances under which they would prefer to use L2, the reasons why they do not use L2, their attitude towards error correction and feedback, as well as the role of the teacher.

Table 1. Mean of the values given to each item in the survey in a scale from 1 to 5.

\begin{tabular}{|c|c|c|c|}
\hline & & Mean & $(1-5)$ \\
\hline & ITEMS & $\begin{array}{l}4^{\circ} \text { ESO } \\
\mathrm{N}=104\end{array}$ & $\begin{array}{c}2^{\circ} \mathrm{BACH} \\
\mathrm{N}=66\end{array}$ \\
\hline Students' perception about the $\mathbf{u}$ & efulness of English & 3,70 & 4,02 \\
\hline Value that the students give to $t$ & le subject & 2,72 & 3,45 \\
\hline It indicates whether the students & use English as much as they would like & 2,53 & 2,20 \\
\hline & teacher-centered & 3,58 & 3,41 \\
\hline It indicates if the class is & organized in small groups & 2,09 & 2,27 \\
\hline 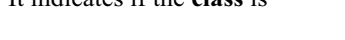 & organized in pairs & 2,03 & 1,94 \\
\hline & based on individual work & 3,32 & 3,70 \\
\hline & for the whole class & 2,09 & 2,12 \\
\hline & to partners they choose & 3,34 & 3,11 \\
\hline $\begin{array}{l}\text { It indicates if the students fee } \\
\text { at ease when talking }\end{array}$ & to partners the teacher coses & 2,66 & 2,44 \\
\hline & in pairs & 2,67 & 2,82 \\
\hline & to the teacher & 2,65 & 2,45 \\
\hline & the teacher is not present & 1,91 & 2,42 \\
\hline at ease to talk if & the teacher is there to help & 3,21 & 3,11 \\
\hline & the teacher is there but s/he doesn't help & 2,95 & 2,77 \\
\hline & interesting debates were organized & 2,69 & 3,27 \\
\hline & their mistakes were not corrected & 2,01 & 2,26 \\
\hline It indicates if the students & their pronunciation was more accurate & 3,58 & 3,45 \\
\hline would use $\mathbf{L} 2$ more if & they had some support while talking & 2,91 & 2,94 \\
\hline & their classmates were not there & 2,54 & 2,53 \\
\hline & they could prepare their speech previously & 3,06 & 3,48 \\
\hline & they are not interested in the topics propose & 2,45 & 2,77 \\
\hline $\begin{array}{l}\text { It indicates whether the } \\
\text { students do not use } \mathbf{L} 2 \text { because }\end{array}$ & they feel embarrassed & 2,83 & 2,74 \\
\hline & of lack of knowledge & 2,89 & 3,00 \\
\hline & to receive feedback on the spot & 4,04 & 3,91 \\
\hline It indicates whether the & to receive feedback when they finish talking & 2,77 & 3,14 \\
\hline students prefer & to receive feedback at the end of the class & 2,42 & 2,70 \\
\hline & not to receive feedback & 1,46 & 1,76 \\
\hline & teacher is a friend & 2,63 & 2,73 \\
\hline It indicates whether the & teacher as instructor & 2,65 & 2,47 \\
\hline & teacher as a source of information & 4,10 & 3,64 \\
\hline & teacher as observer & 2,51 & 3,03 \\
\hline
\end{tabular}


Table 2. presents the percentage of students who feel more relaxed to talk in certain conditions that usually occur in the classroom.

Table 2. Circumstances under which students feel more relaxed to talk

\begin{tabular}{|l|c|c|c|c|c|c|c|c|c|c|c|c|c|c|}
\hline $\begin{array}{l}\text { RELAX (\%) } \\
\text { TO USE L2 }\end{array}$ & \multicolumn{2}{l}{$\begin{array}{l}\text { Talking to } \\
\text { the whole } \\
\text { class }\end{array}$} & $\begin{array}{l}\text { They } \\
\text { choose } \\
\text { partners }\end{array}$ & \multicolumn{2}{l}{$\begin{array}{l}\text { Teacher } \\
\text { decides } \\
\text { partners }\end{array}$} & \multicolumn{2}{l}{$\begin{array}{l}\text { Talking in } \\
\text { pairs }\end{array}$} & \multicolumn{2}{l}{$\begin{array}{l}\text { Talking to the } \\
\text { teacher }\end{array}$} & \multicolumn{2}{l}{$\begin{array}{l}\text { When the } \\
\text { teacher } \\
\text { helps }\end{array}$} & \multicolumn{2}{l}{$\begin{array}{l}\text { Teacher } \\
\text { there but NO } \\
\text { help }\end{array}$} \\
\hline LEVEL & E & B & E & B & E & B & E & B & E & B & E & B & E & B \\
\hline Never & 46,2 & 47 & 18,3 & 21,2 & 22,1 & 30,3 & 28,8 & 31,8 & 24 & 31,8 & 15,4 & 10,6 & 17,3 & 21,2 \\
\hline Sometimes & 17,3 & 16,7 & 11,5 & 12,1 & 22,1 & 22,7 & 17,3 & 12,1 & 21,2 & 25,8 & 12,5 & 19,7 & 23,1 & 18,2 \\
\hline Usually & 24,0 & 19,7 & 21,2 & 18,2 & 32,7 & 24,2 & 23,1 & 15,2 & 29,8 & 16,7 & 28,8 & 30,3 & 24,0 & 33,3 \\
\hline $\begin{array}{l}\text { Very } \\
\text { frequently }\end{array}$ & 6,7 & 10,6 & 16,3 & 31,8 & 13,5 & 18,2 & 19,2 & 24,2 & 15,4 & 16,7 & 22,1 & 27,3 & 18,3 & 16,7 \\
\hline Always & 5,8 & 6,1 & 32,7 & 4,5 & 9,6 & 4,5 & 11,5 & 16,7 & 9,6 & 9,1 & 21,2 & 12,1 & 17,3 & 10,6 \\
\hline
\end{tabular}

The students' answers regarding the extent to which they feel relaxed when the teacher is not present will deserve a special comment as they did not coincide with our premises. It is shown in Figure 2:

Figure 2. Relax when the teacher is not listening

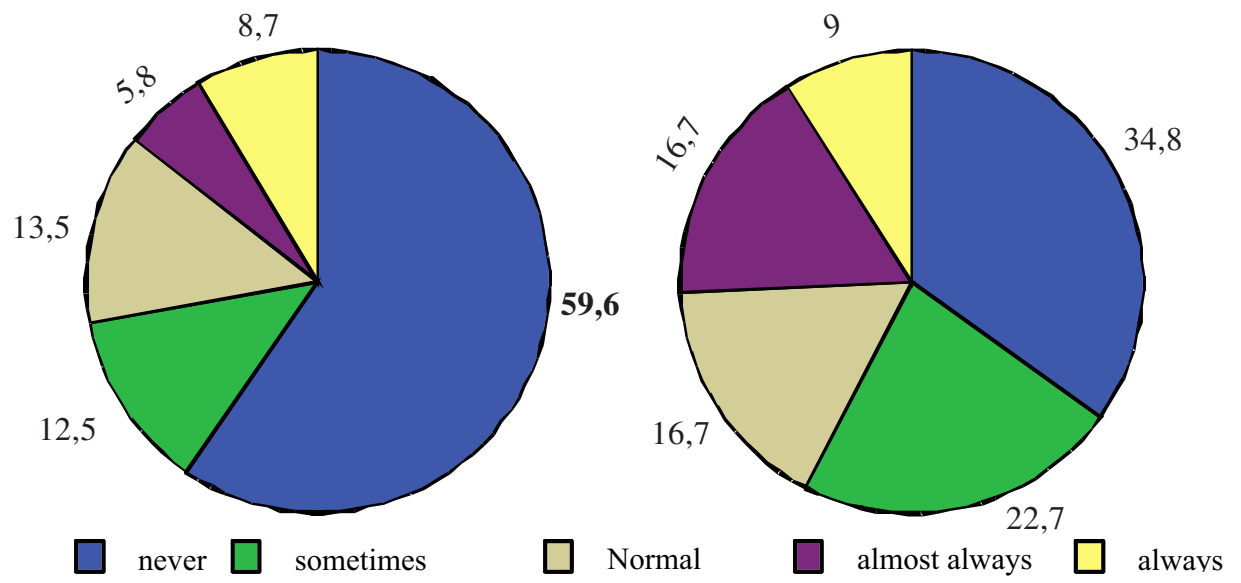

As explained above, there are also personal factors related to the students' personality which also influence them to use L2 in the classroom. They will raise questions such as why sometimes they prefer to stay silent or how they would feel more self-confident to participate in the oral activities. 
Table 3 presents the percentage of students who would participate more if certain circumstances related to the development of such autonomy and self-confidence occurred. Different columns are used to the different levels.

Table 3. Circumstances that promote the use of L2 in the classroom.

\begin{tabular}{|c|c|c|c|c|c|c|c|c|c|c|c|c|}
\hline \multirow{2}{*}{\begin{tabular}{|l}
$\begin{array}{l}\text { PARTICIPA } \\
\text { TION }\end{array}$ \\
LEVEL \\
\end{tabular}} & \multicolumn{2}{|c|}{$\begin{array}{c}\text { If more } \\
\text { knowledge } \\
\text { about English }\end{array}$} & \multicolumn{2}{|c|}{ If no correction } & \multicolumn{2}{|c|}{$\begin{array}{l}\text { With better } \\
\text { pronunciation }\end{array}$} & \multicolumn{2}{|c|}{$\begin{array}{l}\text { With some } \\
\text { support }\end{array}$} & \multicolumn{2}{|c|}{$\begin{array}{l}\text { Without } \\
\text { partners }\end{array}$} & \multicolumn{2}{|c|}{$\begin{array}{l}\text { With chance to } \\
\text { prepare their } \\
\text { speech }\end{array}$} \\
\hline & $\mathrm{E}$ & B & $\mathrm{E}$ & B & $\mathrm{L}$ & B & $\mathrm{E}$ & B & E & B & $\mathrm{E}$ & B \\
\hline Never & 20,2 & 21,2 & 47,1 & 33,3 & 7,7 & 7,6 & 25 & 18,2 & 35,6 & 30,3 & 21,2 & 10,6 \\
\hline on & 23,1 & 16,7 & 23,1 & 33,3 & 11,5 & 12,1 & 11,5 & 13,6 & 13,5 & 10,6 & 8,7 & 13,6 \\
\hline Normal & 21,2 & 24,2 & 17 & 10 & 26,9 & 33,3 & 25 & 34,8 & 2 & 4 & 32,7 & 21,2 \\
\hline \begin{tabular}{|l|} 
Almost \\
always
\end{tabular} & 18,3 & 10,1 & 6,7 & 1,0 & 23,1 & 21,2 & 24 & 22,7 & 15,3 & 9,1 & 18,3 & 25,8 \\
\hline Always & 17,3 & 21,2 & 5,8 & 9,1 & 30,8 & 25,8 & 14,4 & 10,6 & 12,5 & 7,6 & 19,2 & 28,8 \\
\hline
\end{tabular}

There are three of these items worthy to be shown in a different figure due to their importance regarding the differences observed between ESO and Bachillerato. Figure 3 and 4 show the development of extrinsic motivation on the students' use of L2 in the classroom, the former related to the use of topics which interest them and the latter regarding the organization of interesting debates. Figure 5 centers on the degree of shyness and embarrassment on the students and the extent to which these personal constraints hinder them when using L2.

Figure 3. No participation because of no interest in the topics proposed.

ESO

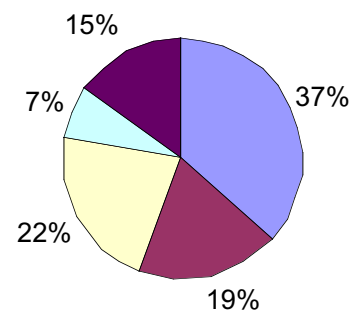

$\mathrm{BACH}$

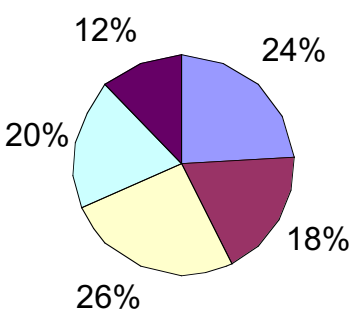

$\square$ Never $\square$ Sometimes $\square$ normal $\square$ Almost always $\square$ always 
Figure 4. Influence of shyness and embarrassment on the students' will to use L2.

ESO

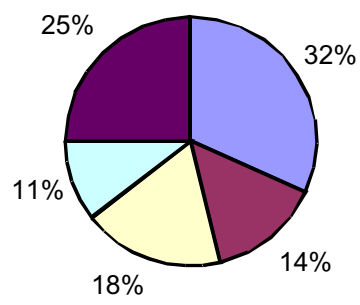

$\mathrm{BACH}$

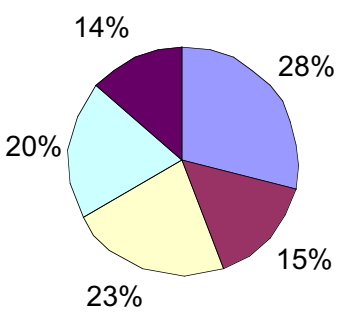

$\square$ Never $\square$ Sometimes $\square$ normal $\square$ Almost always $\square$ always

Figure 5. Percentage of students who would use L2 more if interesting debates were organized.

\section{ESO}

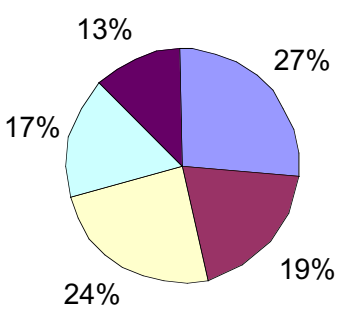

$\mathrm{BACH}$

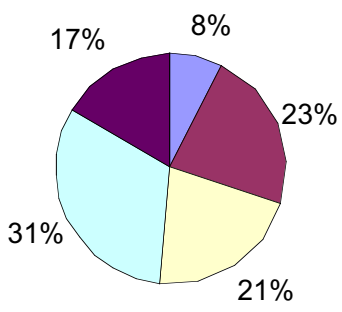

Never $\square$ Sometimes $\square$ normal $\square$ Almost always $\square$ always

Before analysing these questionnaires, we thought error correction would be a main factor to avoid the use of L2 orally. The following table shows the results obtained according to the use of English and the type of feedback received. 
Table 4. Use of L2 related to the type and moment of feedback.

\begin{tabular}{|c|c|c|c|c|c|c|c|c|}
\hline $\begin{array}{c}\text { Error } \\
\text { correction }\end{array}$ & \multicolumn{2}{|c|}{$\begin{array}{c}\text { Feedback at } \\
\text { the end of the } \\
\text { lesson }\end{array}$} & \multicolumn{2}{|c|}{ no correction } & \multicolumn{2}{c|}{$\begin{array}{c}\text { While } \\
\text { participating }\end{array}$} & \multicolumn{2}{c|}{$\begin{array}{c}\text { At the end of } \\
\text { the } \\
\text { participation }\end{array}$} \\
\hline LEVEL & $\mathrm{E}$ & $\mathrm{B}$ & $\mathrm{E}$ & $\mathrm{B}$ & $\mathrm{E}$ & $\mathrm{B}$ & $\mathrm{E}$ & $\mathrm{B}$ \\
\hline Never & 42,3 & 24,2 & 76,9 & 66.7 & 4,8 & 3 & 22,1 & 12,1 \\
\hline Sometimes & 9,6 & 15,2 & 3,8 & 9,1 & 2,9 & 6,1 & 18,3 & 7,6 \\
\hline Normal & 24,0 & 37,9 & 17,3 & 15,2 & 25,0 & 24,2 & 32,7 & 45,5 \\
\hline Almost always & 11,5 & 12,1 & 0 & 0 & 8,3 & 30,3 & 14,4 & 24,2 \\
\hline Always & 12,5 & 10,6 & 1,9 & 9,1 & 49,0 & 36,4 & 12,5 & 10,6 \\
\hline
\end{tabular}

Finally, it is considered that the role of the teacher would be a really important potential to increase or reduce the use of L2 in the classroom. Up to this point, we have study if the students use the L2 as much as desired but the role of the teacher has not been analysed yet. We consider that a teacher who is close to the learners will encourage them to speak in English more than a strict teacher. The most representative figures related to this topic are the following:

Figure 6. Role of the teacher: teacher as a friend.

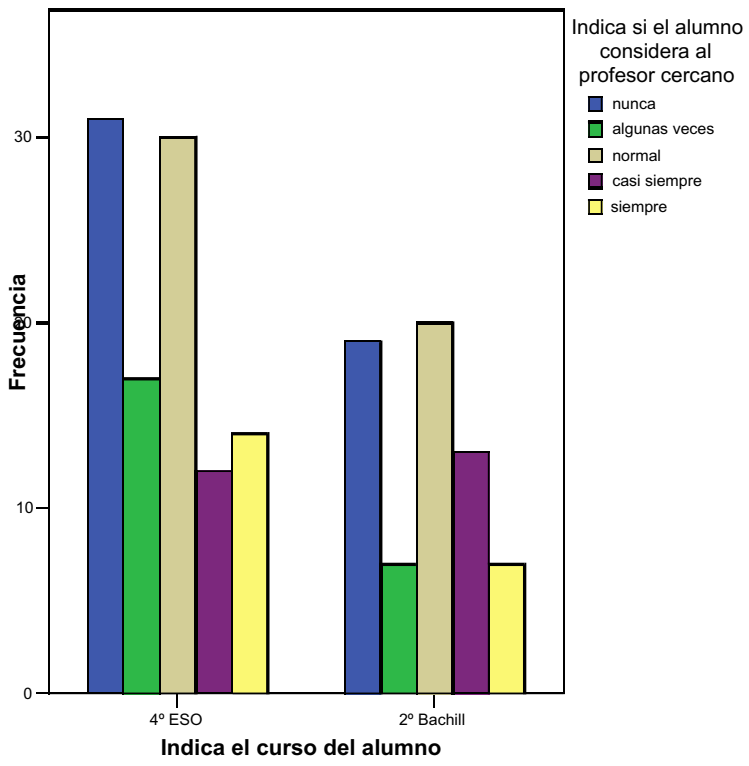




\section{Discussion}

In general, students are motivated to learn L2 since most of them admit the great importance of the subject for their future career and the value that they give to it is usually high. It is important to remark that the opinion about English of students in Bachillerato is more positive than students in ESO. Teachers should take advantage of this growing interest in Bachillerato, change some methodological aspects, and raise the students' motivation with the purpose of making them develop learning autonomy to be able to use L2 and go on studying it in the future. It is significant to point out that most of them, not only in ESO, but also in Bachillerato, admit that they do not use English in the classroom as much as they would like. There are many personal factors intervening in this process, as will be explained below, but the teacher is also a determining figure in it. In ESO, the punctuation when asked if they used English as much as they would like is slightly higher, probably due to the fact that teachers devote more time to the oral skills at this level because they have to concentrate on covering the curriculum at Bachillerato level, since they are constrained by the University entrance exam.

After observing the data obtained, we could appreciate that students are generally intrinsically motivated. This is reflected in the value they give to the subject and in the items represented in Figure 1. This figure shows that motivation is slightly higher in Bachillerato, as they present a higher frequency of use of websites, TV channels, or other publications. This reflects the fact that again learning autonomy is more developed at Bachillerato level since these are resources that the students have to use autonomously. Apart from that, the percentages are not significantly high; these resources are generally used by less than a half of the students, which means that it should be the teacher who raises their motivation by means of extrinsic factors. Around $40 \%$ of them attend private lessons, which shows they are worried about the subject and are aware of its importance. But again it is not a general problem since around $90 \%$ of them passed the subject.

We admitted that motivation leads to learning autonomy and therefore to be more uninhibited to use L2 in the classroom .This implies that if learning autonomy is higher in Bachillerato (as it has been observed) other techniques should be used by the teacher to take advantage of it and make them develop their own capacities. On the other hand, it should also be remarked that this learning autonomy should be fostered at earlier stages so that when students reach Bachillerato it will be fully developed.

Another relevant factor is the use of L2 related to the classroom management, the role of the teacher as well as the usefulness of the L2 for their professional future. The results obtained are completely different from what was expected: $53 \%$ of the participants declare that the teacher is always or almost always the centre of the lesson. Then, the most striking results are obtained when the students are asked how often the class is organized in little groups or in pairs because $45,3 \%$ of them evaluate it as never or hardly ever in little groups and $48,8 \%$ in pairs. $31,2 \%$ of them always work individually. It is difficult to imagine a good rapport and a relaxed atmosphere with those interactional patterns. They do not agree with the frequency they use L2 because the majority think it is not enough. Comparing those results with the classroom management, we find that those who work always individually or the teacher controls the process are not satisfied with their use of L2 in the classroom. 
One of the circumstances to feel more relaxed to use L2 is the interaction pattern. The results are shown on table 2. They feel more at ease when talking to partners that they choose, mainly in ESO, whereas the pattern of interaction which they find most stressful is talking to the whole class. However, there is a point highly surprising that has been reflected on figure 2. It shows the degree to which students feel more relaxed if the teacher is not there. According to the results, it is significant that more than a half of them in ESO prefer the presence of the teacher, which together with those who answered "sometimes" makes almost three quarters of the total; they admit that they do not feel relaxed if the teacher is not present. On the other hand, in Bachillerato they are not so radical to say "never" but the percentage is similar when taking into account "never" and "sometimes". This difference, despite not being very significant, might respond to our premise that older students are more autonomous and are more prone to develop that autonomy.

Regarding teacher's help, neither in ESO nor in Bachillerato do the students give radical answers. Most of them use the medium mark to answer, i.e., "normal". This means that they think that the teacher's help is important but not essential for them to use the oral language in the classroom. They know they have to do it by themselves, but can also appreciate the help of the teacher.

Generally speaking, the marks given to negative categories such as "never" or "sometimes" in these items are much higher than those given to positive ones. This makes us conclude that the extent to which the students feel relaxed to talk in the classroom is not as it should be and the teacher should work to create a relaxing environment. The question is how to do this, so we tried to discover some personal constraints which could be the reasons why they feel anxious or refuse to participate in the classroom.

One of the main reasons why learners decided to remain silent was their fear to fail (Covington, 1985), so we asked if they thought that their lack of knowledge and the fact that they considered that they had bad pronunciation could be important conditioning factors. Another premise was the influence of being corrected in front of everyone, shyness and embarrassment. Then we tried to go for other extrinsic factors such as interest in the topics or organization of controversial debates. The results obtained were usually different from what we expected.

Their knowledge about English was not a significant hindrance for them, since there were not many differences in number between those who answered "always" and those who answered "never." Most of them answered "normal" or "the usual", which lets us think that they would not use the language more if they knew more grammar and/or were more fluent in English. This is because they mainly speak when they are asked to do so, so it is the decision of the teacher, not theirs. In any case, there are divided opinions regarding this matter, which could be studied more accurately in the future.

A higher percentage of them admit they would participate more if they could pronounce more accurately. It is significant the low percentage in both levels who say the opposite. Most of them think that if they need a good pronunciation to speak, so again the teacher should take advantage of that worry and teach oral language, not only sounds but also intonation and rhythm. The learners' worry about the way they "sound" is explained because they are projecting the image of themselves by means of it. Students at this age are developing their self-concept, so this worry obeys to their need to develop their self-image and demonstrate to themselves and to others what Covington (1985) called "self-worth". 
Another important factor is that a very high percentage of students at ESO level would not be affected by the use of interesting topics in the classroom. It has always been thought that students did not participate because the topics are always the same and learners do not know what to say. As it is shown in figure 3, learners' participation is not so much affected by interesting topics. Students in Bachillerato are not so radical again and present lower percentage. The difference could be due to the fact that students in ESO are more worried about other aspects such as shyness, pronunciation, knowledge of English, etc, whereas in Bachillerato they feel they need other external stimuli such as the topics proposed in order to be motivated to speak, perhaps because their autonomy is more developed at this stage. The same happens with the organization of interesting debates, as it can be observed in figure 5. Almost half of them in Bachillerato admit that it is influential because it motivates them, and only $8 \%$ say they would not speak despite the debates. On the other hand, in ESO figures are very different; almost half of them would not speak even though interesting debates were organized and only $30 \%$ would always or almost always speak.

The implications of these conclusions are that the motivation to make students use L2 in the classroom begins inside themselves; they must be both intrinsically motivated and feel self-confident. This has to be the basic layer upon which everything else will stand. The task of the teacher then is to help them reach that confidence, and one of the ways to do is again to develop learning autonomy; teach not only English but also ways to learn English by themselves.

This hypothesis is again corroborated by the fact that most students in Bachillerato admit that they would speak more if they could prepare their speech previously. This plan of what they are going to say is an individual process which they have to do autonomously, so it confirms their need to be autonomous in order to feel confident enough. At ESO level figures are different; not many of them admit this would be a helping tool to make them use more L2 perhaps because they have not tried so far or they think they would need the help of the teacher as well.

One of the most striking results for us was the one related to the correction of mistakes. It is very significant that a very low percentage of them $(5,8 \%$ in ESO and $9,1 \%$ in Bachillerato) would speak if there was no correction, so this implies that a very high percentage of them consider correction a factor which can help them in their oral speech. They generally prefer being corrected, they need the feedback and the approval of the teacher. This is an item on which both levels agree. Then, when they are asked if they would prefer not to be corrected, student of ES0 slightly prefer it $(76,9 \%)$ in comparison with those who do not want to be corrected (1,9\%). In Bachillerato the rate is almost similar, only $9,1 \%$ prefer not to be corrected. It is clear enough the necessity of the teacher as it has been commented above. In relation to the different moments a student can receive feedback, in Bachillerato, they consider it is better to correct them while their participation rather than a general comment at the end of the lesson about all the mistakes. In Eso this result is more specific and radical $(42,3 \%)$ than in Bachillerato $(24,2 \%)$. It was a surprising result due to the fact that our hypothesis was that the moment of error correction would be definitely decisive for their participation and that they would prefer a general comment not a personal one. What is more, we consider that the age would be determinant and, because of some personal features commented above, students of ESO would not prefer it. It would be a n interruption of the learners' flow which could cause the learner to lose the thread of what they were saying. 
After all these commented data, we can affirm that an interesting point under evaluation would be the role of the teacher. Traditionally, the teacher should have the control of the classroom. He designed lesson plans which included correcting error in grammar and vocabulary. However, the problem is that this planning did not take care about oral communication. English language in this kind of lessons was not the appropriate use of the language, in other words, it was not the language of everybody but a useless one. Nowadays, it is trendy to teach according to the communicative method and task based activities to obtain a more realistic atmosphere. But, is it close to classrooms' reality? Unfortunately, the answer is no. This is the expected situation but what we find analysing our surveys is a complete different one. Almost all the lessons are teacher-centered so there is not enough time for students' participation. It is also relevant to comment that the rate of students who disagree with the time used for oral skills in English is quite similar to those who affirm that they have nothing to do at lessons because everything is done by the teacher. However, some scholars think that students work better under strict teacher supervision. (Madrid, 1996: 34-35)

The results confirm that if you do not follow the last trendy methods, it does not mean it is wrong because a high average of students have passed the English subject although they declare not being satisfied with the use of L2 in the classroom and not participating actively in the lessons. We can conclude that there is not a close relation between the oral practise of L2 and the passing of the subject. However, it should not be a problem we may avoid because the best way to improve a language is using it in the more realistic context as possible.

According to what the data showed, we can conclude by remarking that the already proposed techniques in a theoretical way to enhance the students' motivation to participate in the classroom (vary interaction patterns, give feedback, provide good rapport or use motivating topics in the classroom) are efficient when tried, but they are seldom brought into practice. We think that teachers' supervision is necessary as long as he/she does not prevent the students from developing their learning autonomy. To foster autonomy and self-worth must be the first step for teachers even before implementing motivation by means of other techniques. Thus students will feel confident enough and will trust their own abilities in order to use L2 in the classroom without any kind of restriction.

\section{REFERENCES}

Bygate, M. (1987). Speaking. Oxford: OUP.

Byrne, D. (1987). Teaching for oral interaction. London: Longman.

Covington, M.V. (1985). "The Motive for Self-worth", in Ames, C. and R. Ames (eds.), Research on Motivation in Education. Vol. 1. N.Y.: Academic Press.

Dörnyer, Z. Kormos, J. (2000). "The role of individual and social variables in oral Task performance", in Language research, 4-3: 275-300.

Foster, P. (1998). "A classroom perspective on the negotiation of meaning". Applied Linguistics 19 (1): $1-23$.

Gómez, Ma T. et al. (1990). Propuestas de interacción en el aula. Técnicas para lograr un clima favorable en la clase. Madrid: Nancea. 
Hadley, G. "Encouraging oral communication in the EFL classroom". Available at http:// www.nuis.ac.jp/ Hadley/ publication/partpoints/participation.htm

Halliday, M.A.K. (1989). Spoken and Written Language. Oxford: OUP.

Hernández, M., Hornillo, P., Picó, E. (1991). "Variables afectivas en la adquisición de la segunda lengua", in IX Congreso Nacional de la Asociación Española de Lingüística Aplicada (AESLA), San Sebastián, 9-12.

Lister, R., Ranta, L. (1997). "Corrective feedback and learners uptake: Negotiation on form in communicative classrooms", in Studies in Second Language acquisition, 19: 37-66.

Littlewood, W. (1992). La enseñanza de la comunicación oral. Barcelona: Paidós.

Madrid, D. (2004). Importancia de las Características individuales del profesorado en los procesos de enseñanza y aprendizaje de las lenguas extranjeras. Granada: Editorial Universidad de Granada.

Madrid, D. and McLaren, N. (eds.) (1996). A Handbook for TEFL. Alcoy: Marfil.

Nikolov, M. (1999). “'Why do you learn English?' 'Because the teacher is short.'. A study of Hungarian children's foreign language learning motivation”, in Language Teaching Research 3,1; 33-56.

Ortega Martín, J.L. and Villoria Prieto, J. (2004). "Classroom Research”, TEFL in Primary Education. Granada: Universidad de Granada.

Oxford, R. (2001). "Integrated skills in the ESL/EFL classroom". ERIC Digest. In Eric Clearinghouse on languages and linguistics Washington DC. ED 456670.

Stabb, C. (1986). "What Happened to the Sixth Graders: Are Elementary Students Losing their Need to Forecast and to Reason?", in Reading Psychology, 7,4: 289-96.

Spratt, M., Humphreys, G., and Chan, V. (2002). "Autonomy and motivation: which comes first?", in Language Teaching Research 6,3: 245-266.

Stern, (1991). Fundamental Concepts of Language Teaching. Oxford University Press.

Walsh, S. (2002). "Construction or obstruction: teacher talk and learner involvement in the EFL classroom", in Language Teaching Research 6,1: 3-23.

YoungHee Sheen (2004). "Corrective feedback and learner uptake in communicative classrooms across instructional settings", in Language research, 263-300.

Zhang, H. and Aiex, N. K. (1995). "Oral Language development across the curriculum, K-12". ERIC Digest, in ERIC Clearinghouse on Reading, English, and Communication Bloomington. ED 389029.

Zhang, H., Nola Karter, A. "Oral Language development across the curriculum", Eric Digest Bloomington in ERIC Clearinghouse on Reading, English, and Communication. ED 389029. 